\title{
PURCHASE DECISION IN VIEW OF BRAND IMAGE, PRODUCT QUALITY, AND PROMOTION
}

\author{
Ika Istikhomah*1, Fithri Setya Marwati ${ }^{2}$ \\ Universitas Islam Batik, Indonesia*12 \\ ikaistikhomah3@gmail.com¹ , fithri marwati@yahoo.com²
}

\begin{abstract}
The development of technology at this time is very fast. This development can be seen from the progress of gadgets that are now easily grasped by various groups (rich, poor) and ages (old, young) all can use it. Gadget innovations are always popping up all the time, from laptops, PCs, to cellphones. Mobile offers various advantages and features to support user flexibility. This study aims to prove the simultaneous and partial effect of purchasing decisions in terms of brand image, product quality, and promotion of Oppo mobile phones. This research is quantitative descriptive. The population is all buyers of Oppo mobile phones. The number of samples used amounting to 100 respondents, the sample was taken by purposive sampling technique. The data analysis technique used in this study was multiple linear regression analysis. The results show that the f-test brand image, product quality, and promotion simultaneously and significantly influence the buying decision for Oppo mobile phones. The t-test results show that brand image has a positive and significant effect on purchasing decisions for Oppo cellphones, product quality has a positive and significant effect on purchasing decisions for Oppo cellphones, the promotion has a positive and significant effect on purchasing decisions for Oppo cellphones.
\end{abstract}

Keywords: Brand Image; Product Quality; Promotion; Purchasing Decisions

\section{INTRODUCTION}

Current technological developments can be seen from the advancement of gadgets that are now easily grasped by various groups (rich, poor) and ages (old, young) all can use them. Gadget innovations are always popping up all the time, from laptops, PCs, to cellphones. Mobile offers various advantages and features to support the flexibility of its users The Covid-19 pandemic which attacks almost all parts of the world, including Indonesia, made the government set the PSBB (Large-Scale Social Restrictions) which made school learning, meetings, and office work (business) ) conducted online using the zoom application and google classroom which can be accessed using gadgets and cellphones. This forces all groups to have cellphones and gadgets to support school and work activities. Cellphone manufacturers see this opportunity, how people use cellphones to support their activities.

A good producer can read the wishes of the people. Manufacturers are competing to provide products that most attract consumers. Nowadays the brand of a product can determine a purchase decision from consumers. Indonesian people often think that foreign brands are always better than domestic brands. The behavior of Indonesian consumers who like branded goods considers that buying foreign products can improve their image or prestige. It can be seen that the decision of Indonesian consumers to buy something is influenced by a large enough brand image.

Sagita (2013), states that brand image is a broad description or description of consumer perceptions of a brand. Fachry \& Azhari (2020), product image influences purchase decisions based on customer perceptions of the product or service being offered which is directly proportional to the purchase decision. In addition to the brand image, the Indonesian people also pay attention to product quality. The quality of the cellphone can be seen through the capacity, features, and functions contained therein. Margiyanto (2013), argues that product quality is the product's competitiveness 
compared to its competitors through its capabilities (durability, efficiency, and other values). Consumers will conduct a comparative analysis of products to obtain the desired specifications. Prasetyo \& Purwantini (2017), product quality affects purchasing decisions. A strategic weapon and a powerful shield to beat the competition are through product quality. Manufacturers who consistently prioritize quality can be sure to grow well and are in demand by the market.

The purpose of operating the company is to fulfill customer wants and needs. If a company wants to be known and exist, it must pay attention to market interests, wants and expectations. The way to meet market expectations and desires is to communicate through various things, the aim is to provide more value to consumers than its competitors. Communication with consumers is usually through the suggestion box provided by the company to listen to consumer complaints, distribute questionnaires, and often through direct interviews. The variable that is closely related to purchasing decisions is promotion. Promotion is the business of providing a service or company to provide information to the public and the market regarding the products offered, the place and time they take effect Sagita (2013) state that promotion affects customer satisfaction.

Promotional activities have a period and the goal is to stimulate consumer purchases, promotions have the same direction as consumer decisions in buying, meaning that if consumers agree and buy a product, the promotion or advertisement carried out by the company is successful in attracting consumers. Oppo mobile phones are well-known vendors in Indonesia. Oppo is known to reach small areas in Indonesia. Oppo mobile phones are known to have durable or long-lasting performance, features, and durability. With various specifications and affordable prices, Oppo mobile phones can be reached by all levels of society. Oppo is a vendor who is diligent in bringing out innovations and new models. Oppo mobile phones are one of the most sought-after and best-selling smartphones in the Indonesian market. Through the quality of Oppo products, the selfie camera and rear camera are good, have fast charging technology, and have an attractive design. Oppo also has shortcomings in the area of product quality, including rarely providing heavy OS and color OS updates, and build quality is not as good as competitors.

The brand image and promotions built by Oppo are quite interesting, including producing cellphones according to market tastes and massive marketing strategies to make Oppo widely known to the public, but there is one drawback, namely the price of Oppo overpriced and making the price of second Oppo decrease so rapidly. Singosaren Plaza is a meeting place for sellers and buyers of mobile phones, both new and second, which are all available at Singosaren Plaza. This plaza is well known in the city of Solo and is the main destination for people when hunting for cell phones.

Oppo mobile phones are the most marketed cellphones in every Singosaren outlet because Oppo is promoting vigorously at each outlet, this has an impact on Oppo's sales or purchase decisions to increase every month. The increase in purchasing decisions occurred because the sales targets were set for all Oppo sales at Singosaren Plaza. From the description above, it can be seen that several problems need to be fixed by Oppo Smartphone to increase consumer purchasing decisions at Singosaren Plaza through the brand image, product quality, and promotion, so the authors took the research with this study.

An image cannot be controlled by producers, arises automatically along with the progress of economic activity between producers and consumers through advertisements, promotions, production, purchases, payments, and other means used by producers to attract prospective consumers' days. Healthy competition can be created because of the quality created by various manufacturers, a competitive spirit, and want to maintain the product go hand in hand with product improvements to suit market 
desires. A product is considered perfect or of good quality, if it emphasizes the principles of productivity, efficiency, and effectiveness in the aspects of cost, labor, and supply, by avoiding mistakes, and repetitive work. Repetitive work will be detrimental to producers in terms of quality and cost.

Promotion is a means owned by producers to introduce their products to the public through the value and innovation of the products they produce. The promotion aims to provide product introduction, explanation of specifications which aim to lure consumers to have the desire to buy an item (Rawung \& Sumarauw, 2015). The research objective was to see the effect simultaneously, product quality and the price of the Oppo Mobile purchase decision. To analyze and analyze the influence of brand image on the decision of Oppo Mobile. To see the effect of product quality on the Oppo Mobile decision. There is no promotional effect on the decision to buy an Oppo mobile.

\section{METHODS}

This research method is quantitative through a descriptive approach. The data analysis technique used in this study was multiple linear regression analysis. Conducted September 2019 to January 2020 at Singosaren Plaza, which is located at Jalan Gatot Subroto No. 27-28 Kemlayan, Serengan District, Surakarta City, Central Java. A population is a person who generally has an attachment to the research taken. The population of this research is the visitors to the Singosaren Plaza. The population is not known for the exact number each month or is not infinite. The sampling technique of this research is judgmental, so 100 respondents were obtained from visitors to Plaza Singosaren, namely consumers of Oppo mobile phones.

\section{RESULTS AND DISCUSSION}

Table 1. Validity Test Results

\begin{tabular}{cccc}
\hline Statement & $\mathbf{r}_{\text {count }}$ & $\mathbf{r}_{\text {table }}$ & Description \\
\hline Purchase Decision (Y) & & & \\
Statement 1 & 0.794 & 0,3739 & Valid \\
Statement 2 & 0.678 & 0,3739 & Valid \\
Statement 3 & 0.734 & 0,3739 & Valid \\
Statement 4 & 0.891 & 0,3739 & Valid \\
Statement 5 & 0.909 & 0,3739 & Valid \\
Brand Image (X1) & & & \\
Statement 1 & 0.802 & 0,3739 & Valid \\
Statement 2 & 0.771 & 0,3739 & Valid \\
Statement 3 & 0.729 & 0,3739 & Valid \\
Statement 4 & 0.846 & 0,3739 & Valid \\
Statement 5 & 0.745 & 0,3739 & Valid \\
Product Quality (X2) & & & \\
Statement 1 & 0.620 & 0,3739 & Valid \\
Statement 2 & 0.760 & 0,3739 & Valid \\
Statement 3 & 0.901 & 0,3739 & Valid \\
Statement 4 & 0.866 & 0,3739 & Valid \\
Statement 5 & 0.781 & 0,3739 & Valid \\
Promotion (X3) & & & \\
Statement 1 & 0.846 & 0,3739 & Valid \\
Statement 2 & 0.732 & 0,3739 & Valid \\
Statement 3 & 0.696 & 0,3739 & Valid \\
\hline
\end{tabular}




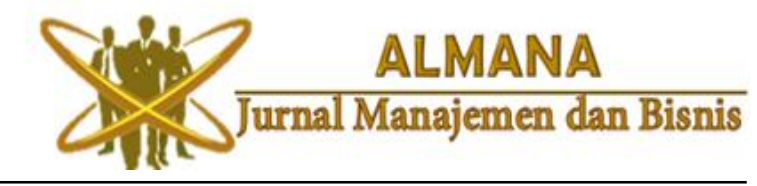

\begin{tabular}{llll}
\hline Statement 4 & 0.863 & 0,3739 & Valid \\
Statement 5 & 0.847 & 0,3739 & Valid \\
\hline
\end{tabular}

Source: Primary data processed (2020)

The results of the above validity state that the 20 statement items presented to 30 respondents with a minimum validity index value of 0.3739 , then all statements can be used as a questionnaire in research.

\section{Table 2. Reliability Test Results}

\begin{tabular}{lccc}
\multicolumn{1}{c}{ Variable } & Cronbach Alpha & Nunnally criteria & Description \\
\hline Buying decision & 0.808 & 0,600 & Reliable \\
Brand Image & 0.799 & 0,600 & Reliable \\
Product quality & 0.804 & 0,600 & Reliable \\
Promotion & 0.804 & 0,600 & Reliable \\
\hline
\end{tabular}

Source: Primary data processed (2020)

Reliability test can be done using the SPPS version 22 program by selecting the analysis menu then selecting the scale then selecting reliability analysis. The results of the analysis are obtained through Cronbach Alpha and the results of the reliability test in this study are contained in the table and the results show reliability. Judging from the results according to the table above, all variables have been above 0.5 and are declared reliable.

Table 3. Multiple Linear Regression Test Results

\begin{tabular}{lccc}
\hline \multicolumn{1}{c}{ Variabel } & $\mathrm{B}$ & $\mathrm{T}_{\text {count }}$ & Sig \\
\hline Constant & 0,615 & 0,491 & 0,625 \\
Brand Image & 0,329 & 4,355 & 0,000 \\
Product quality & 0,328 & 4,299 & 0,000 \\
Promotion & 0,348 & 4,411 & 0,000 \\
$R_{2}: 0,702$ & & $F_{\text {count }}: 75,287$ & \\
Adjusted R2: $: 0,692$ & & $\mathrm{~F}_{\text {sig }}: 0,000$ & \\
\hline
\end{tabular}

Source: Primary data processed (2020)

$$
Y=0,615+0,329 X_{1}+0,328 X_{2}+0,348 X_{3}+e
$$

Based on the table data obtained:

$\mathrm{b} 1=0.329, \mathrm{~b} 2=0.328, \mathrm{~b} 3=0.348$ and $\alpha=0.615$

Then a regression analysis can be arranged as follows:

$Y=a+b 1 X 1+b 2 X 2+b 3 X 3+e$

$Y=0.615+0.329 X 1+0.328 X 2+0.348 X 3+e$

Table 4. The Results of the Determination Coefficient Test

\begin{tabular}{cccc} 
Model & $\mathrm{R}$ & R Square & Adjusted R Square \\
\hline 1 & 0,838 & 0,702 & 0,692 \\
& Source: Primary data processed (2020) &
\end{tabular}

Based on the above analysis, is obtained R2 0.692 or $69.2 \%$. This means that the variables of brand image, product quality, and promotion have a $69.2 \%$ effect on 
purchasing decisions for Oppo mobile phones. The remaining $30.8 \%$ is influenced by variables not found in this study.

Table 5. F-Test Results

\begin{tabular}{ccccccc}
\hline Model & $\begin{array}{c}\text { Sum Of } \\
\text { Squares }\end{array}$ & DF & $\begin{array}{c}\text { Mean } \\
\text { Square }\end{array}$ & $F$ & Sig & Description \\
\hline Regression & 475,945 & 3 & 158,648 & 75,287 & 0,000 & Significance \\
Residual & 202,295 & 96 & 2,107 & & & \\
Total & 678,240 & 99 & & & & \\
\hline
\end{tabular}

Source: Primary data processed (2020)

Based on the table $F$-test results show the value of $F_{\text {count }} 75.287>F_{\text {table }}$ which is 2.70 with a significance of 0.000 which means $<0.05$. From these values, $X 1, X 2, X 3$ have a simultaneous effect on $Y$ (the decision to buy an Oppo Mobile) at Singosaren Plaza.

Table 6. T-Test Results

\begin{tabular}{lcccc}
\hline \multicolumn{1}{c}{ Variabel } & $\mathrm{T}_{\text {table }}$ & $\mathrm{T}_{\text {count }}$ & Sig. & Description \\
\hline Brand Image & 4,355 & 1,984 & 0,000 & Ho rejected \\
Product quality & 4,299 & 1,984 & 0,000 & Ho rejected \\
Promotion & 4,411 & 1,984 & 0,000 & Ho rejected \\
\hline \multicolumn{5}{c}{ Source: Primary data processed $(2020)$} \\
\end{tabular}

Through the T-test table can be explained the test results: It is known that $\mathrm{X} 1$ shows $t_{\text {count }}(1.984)>t_{\text {table }}(4.355)$ and $t_{\text {sig }}(0.000)$ is smaller than $\alpha(0.05)$, so the brand image has a positive and significant effect on purchasing decisions for Oppo mobile phones in Singosaren. Plaza. It is known that X2 shows $t_{\text {count }}(1,984)>t_{\text {table }}(4,299)$ and $t_{\text {sig }}(0,000)$ is smaller than $\alpha(0.05)$, so product quality has a positive and significant effect on purchasing decisions for Oppo mobile phones at Singosaren Plaza. It is known that X3 shows $t_{\text {count }}(1.984)>t_{\text {table }}(4.411)$ and $t_{\text {sig }}(0.000)$ smaller than $\alpha(0.05)$, so promotion has a positive and significant effect on the purchasing decision for Oppo Singosaren Plaza Mobile.

The results of this study state "There is a positive and significant brand image influence on the purchasing decision for Oppo mobile phones at Singosaren Plaza". Brand image is a form of thought, expression, and consumer benefits for works. Image cannot be controlled by producers, arises automatically along with the progress of economic activity between producers and consumers through advertisements, promotions, production, purchases, payments, and other means used by producers to attract prospective consumers' days. Purchase decisions are based on consumers' perceptions or assumptions that the products or services offered are directly proportional to the decision to buy the product.

The results of this study state "There is a positive and significant effect of product quality on the purchasing decision for Oppo Mobile at Singosaren Plaza". Healthy competition can be created because of the quality created by various manufacturers, a competitive spirit, and want to maintain the product go hand in hand with product improvements to suit market desires. A product is considered perfect or of good quality, if it emphasizes the principles of productivity, efficiency, and effectiveness in the aspects of cost, labor and supply, by avoiding mistakes, and repetitive work. Repetitive work will hurt the producer in terms of quality and cost. A strategic weapon and a powerful shield to beat the competition are through product quality. Manufacturers who consistently prioritize quality can be sure to grow well and are in demand by the market. 
The results of this study state "There is a positive and significant effect of promotion on the decision to buy an Oppo Mobile at Singosaren Plaza".

The reason is that promotional activities have the time and purpose to stimulate the purchasing power of potential consumers, promotions go hand in hand with purchasing decisions, the more intense and attractive promotions, the increased product purchasing decisions. Promotion should not be done carelessly so that potential buyers are interested and have the desire to buy goods. Handphone Oppo is one of the Handphones that are actively promoting. Promotion is carried out through social media, Instagram, Twitter, youtube, and television media, in the form of discounts, discounts with certain conditions or prices, and offers, through television advertisements, sponsoring events, and presenting attractive features which are proven to attract customer interest, not only limited to promos and advertisements, Handphone Oppo collaborates with many artists and celebrities for Oppo products.

\section{CONCLUSION}

Brand image, product quality, and promotion simultaneously influence the purchasing decision for Oppo Mobile. Brand image has a positive and significant effect on purchasing decisions for Oppo mobile phones. Product quality has a positive and significant effect on the purchase decision for Oppo Mobile. The promotion has a positive and significant effect on the decision to buy an Oppo mobile.

\section{REFERENCES}

Fachry, Mohammad Frisky \& Azhari, Rafi Dimas. (2020). Pengaruh Citra Merek dan Promosi terhadap Keputusan Pembelian Batik Karawang di Ramayana Mall, Karawang. Jurnal Ilmiah Manajemen Ubhara, 2(1).

Margiyanto, M. (2013). Analisis Pengaruh Citra Merek, Persepsi Harga, Kualitas Produk, dan Promosi Terhadap Keputusan Pembelian Balckberry di kota Semarang. Universitas Diponegoro.

Prasetyo, Eko Teguh \& Purwantini, Sri. (2017). An Influence Analysis Of Product Quality, Brand Image, and Price On the Decision To Buy Toshiba Laptop. Economics \& Bussiness. Solutions Journal, 1(2).

Rawung, D.R., Oroh, S., \& Sumarauw, J. (2015). Analisis Kualitas Produk, Merek Dan Harga Terhadap Kepurusanpembelian Sepeda Motor Suzuki Pada Pt.Sinar Gale.song Pratama Manado. Jurnal EMBA, 3(3), p.1298-1308.

Sagita, Fitria Engla. (2013). Pengaruh Brand Image dan Harga Terhadap Keputusan Pembelian Ulang Produk Kentucky Fried Chiken (KFC) di Cabang Bakso Grand Mall. Universitas Negeri Padang. 